\title{
THE NEW CHAUCER SOCIETY
}

\author{
President \\ Executive Director \\ Advisory Trustees
}

Trustees 2018-2022

Trustees 2020-2024

Editors, Studies in the Age of Chaucer

Book Review Editor

Editorial Assistants

Advisory Board

Administrative Assistant

Bibliographer

Assistant Bibliographer

Online Chaucer

Bibliographer
Anthony Bale, Birkbeck College, University of London

Thomas Goodmann, University of Miami

Simon Horobin, Magdalen College, Oxford

Patricia Ingham, Indiana University, Bloomington

Emily Steiner, University of Pennsylvania

Seeta Chaganti, University of California, Davis

David Raybin, Kent State University

Marion Turner, Jesus College, Oxford

KARMA Lochrie, Indiana University, Bloomington

Robert Meyer-Lee, Agnes Scott College

Sif RíkHARĐSDÓtTIR, University of Iceland

Kellie Robertson, University of Maryland

Michelle Karnes, University of Notre Dame

Sebastian Sobecki, University of Groningen

Jennifer Jahner, Caltech

Aline Douma, University of Groningen

Logan Quigley, University of Notre Dame

Ardis Butterfield, Yale University

Susan Crane, Columbia University

Carolyn Dinshaw, New York University

Ruth Evans, Saint Louis University

Richard Firth Green, Ohio State University

Alastair Minnis, Yale University

E. Paige Miller, University of Miami

Stephanie Amsel, Southern Methodist University

WILl Rogers, University of Louisiana at Monroe

Mark Allen, University of Texas, San Antonio

Studies in the Age of Chaucer, the yearbook of The New Chaucer Society, is published annually. Each issue contains substantial articles on all aspects of Chaucer and his age, book reviews, and an annotated Chaucer bibliography. Manuscripts should follow the Chicago Manual of Style, 16th edition. Unsolicited reviews are not accepted. All correspondence regarding manuscript submissions should be directed to the Editors, Michelle Karnes and Sebastian Sobecki, studiesintheageofchaucer@gmail.com. Subscriptions to The New Chaucer Society and information about the Society's activities should be directed to Tom Goodmann, chaucer@miami.edu. Back issues of the journal may be ordered from University of Notre Dame Press, c/o Longleaf Services, Inc., 116 S. Boundary St., Chapel Hill, N.C. 27514-3808; email: orders@longleafservices.org; phone: 800-848-6224; fax: 800-272-6817; from outside the United States, phone: 919-966-7449; fax: 919-962-2704. 